\title{
Cohorting of Non-Critically Ill COVID-19 Patients: A Multicenter Survey Study (COVID-COHORT)
}

\author{
Ushma Purohit, HBSc ${ }^{1,2}$, Mike Fralick, MD, PhD, SM ${ }^{3,4}$
}

1. University of Toronto, Faculty of Medicine, Toronto, Canada

2. Institute of Health Policy, Management and Evaluation, University of Toronto, Toronto, Canada

3. Sinai Health System and the Department of Medicine, University of Toronto, Toronto, ON, Canada

4. University of Toronto, Department of Medicine, General Internal Medicine, Toronto, Canada

Correspondence: $\quad$ Michael Fralick, MD, PhD, SM, FRCPC

Sinai Health System

60 Murray Street

M5T 3L9

email: mike.fralick@mail.utoronto.ca

Tables: 0

References: 6

Word count: 881

Keywords: COVID-19, coronavirus, patient, cohort, placement, hospital 
COHORTING OF COVID-19 PATIENTS

\begin{abstract}
:
The COVID-19 pandemic has posed novel infection-control challenges for hospitals around the globe. One infection-control strategy that has been widely used in the context of other outbreaks is patient cohorting. This strategy refers to the placement of all patients exposed to the same laboratory-confirmed infectious agent in one location within the hospital. Little is known about the current utilization of this strategy with non-critically ill COVID-19 patients. An international multicenter, survey study was conducted to identify what strategies are planned or in place for patients with COVID-19 who are not critically ill. The survey was distributed from March 2329th, 2020 to GIM physicians in Canada, USA, Denmark, Singapore, Hong Kong, and England. Of the 31 hospitals, 29 (94\%) indicated that they plan on cohorting all GIM patients with COVID-19 to one location in the hospital. Among these 29 hospitals, 23 (79\%) had implemented the plan at the time of the survey. The primary reasons for this decision were to limit the spread of COVID-19 and conserve PPE use. In conclusion, in the face of a novel virus there is near unanimity in the practice of patient cohorting as a potential mitigation strategy.
\end{abstract}


COHORTING OF COVID-19 PATIENTS

\section{Introduction:}

Severe acute respiratory syndrome coronavirus 2 (SARS-CoV-2) is a novel coronavirus that has been identified as the cause of the coronavirus disease 2019 (COVID-19). As of May 24, 2020, there were over 5.31 million cases reported worldwide and over 342,000 deaths. ${ }^{1}$

Patient cohorting is an infection control strategy frequently employed in the context of the current COVID-19 outbreak. There are no formal guidelines on whether patients who are noncritically ill should be cohorted in the same geographic location. However, The Centre for Disease Control and the European Centre for Disease Prevention has advised that facilities consider designating units within the hospital, along with dedicated healthcare providers (HCP), to care for known or suspected COVID-19 patients. $^{2}$ This recommendation has been made to limit HCP exposure and to conserve Personal Protective Equipment (PPE). ${ }^{2}$ The objective of our study was to determine the current policies and procedures enacted for cohorting of noncritically ill patients. 
COHORTING OF COVID-19 PATIENTS

\section{Methods:}

We conducted an international, multicenter, survey study to identify the strategies planned (or in place) for patients with COVID-19 who are not critically ill and admitted to General Internal Medicine (GIM). We focused on GIM because this is the most common service caring for noncritically ill patients with COVID-19 based on data from countries that were affected earlier by COVID-19.

The survey was distributed from March 23-29 ${ }^{\text {th }}, 2020$ via email. Survey respondents included GIM physicians from Canada, USA, Denmark, Singapore, Hong Kong, and England. Physicians were not asked for any self-identifying information and were ensured that results would be reported at the regional level and not at the hospital-level. The survey included multiple-choice questions (Yes/No) about whether the physician's hospital had plans for patient cohorting and whether the plans had already been implemented. They were also asked to provide reasoning behind their hospital's decision on whether to implement patient cohorting using an open-ended short-answer format. The study was exempt from Research Ethics Board approval. Descriptive statistics were used to summarize the data. 
medRxiv preprint doi: https://doi.org/10.1101/2020.11.01.20194233; this version posted November 4, 2020. The copyright holder for this preprint

(which was not certified by peer review) is the author/funder, who has granted medRxiv a license to display the preprint in perpetuity.

It is made available under a CC-BY-NC-ND 4.0 International license.

COHORTING OF COVID-19 PATIENTS

\section{Results}

Responses were provided from 31 hospitals, of which 20 were from Canada (15 from Ontario,

Canada). Of the 31 hospitals, 29 (94\%) indicated that they plan on cohorting all GIM patients

with COVID-19 to one location in the hospital. Among these 29 hospitals, 23 (79\%) had

implemented the plan at the time of the survey. The main reasons for cohorting were to minimize

nosocomial spread of COVID-19 and conserve PPE. Six hospitals did not have any plans to

implement patient cohorting. Survey respondents stated this was because there were no admitted

individuals with COVID-19 at the time of completing this survey. 
COHORTING OF COVID-19 PATIENTS

\section{Discussion}

In the face of a novel virus there is near unanimity in the practice of patient cohorting as a potential mitigation strategy. Of the 31 included hospitals, 29 have decided to cohort patients onto one geographic location. The primary reasons for this decision were to limit the spread of COVID-19 and conserve PPE use.

Our findings align with the measures taken by several hospital sites during the Taiwan SARS outbreak. ${ }^{3}$ One study reported 0.03 cases/bed in hospitals with cohorting vs 0.13 cases/bed in hospitals without $(\mathrm{P}<0.03) .{ }^{4}$ Patient cohorting, by virtue of permitting PPE resuse, has also been shown to decrease PPE shortages. According to the World Health Organization, in the event of PPE shortages, HCPs may wear the same respirator while caring for multiple patients with COVID-19, in the same isolated location. ${ }^{5}$ Cohorting may also contribute to containing the widespread contamination of the healthcare environment that has been documented in the setting of SARS-CoV-2. ${ }^{6}$ Specifically, in areas of the hospital where patient cohorting occurred, the ability to detect SARS-CoV-2 was 4-fold higher than in areas where there were no patients with COVID-19. ${ }^{6}$ Important limitations to our study include the lack of a systematic survey strategy and the lack of information on the rate of nosocomial outbreaks of respiratory pathogens within the participating hospitals.

As COVID-19 continues to pose novel challenges for hospitals across the globe, it becomes vital for healthcare communities to share best practices and learn from one another. Our multicenter, international survey identified that all hospitals with active cases of COVID-19 on GIM wards are practicing patient cohorting. 
medRxiv preprint doi: https://doi.org/10.1101/2020.11.01.20194233; this version posted November 4, 2020. The copyright holder for this preprint

(which was not certified by peer review) is the author/funder, who has granted medRxiv a license to display the preprint in perpetuity.

It is made available under a CC-BY-NC-ND 4.0 International license.

\section{Acknowledgements:}

We would like to thank Dr. Christopher Kandel, Dr. Michael Colacci, Dr. Sagar Rohailla and

Nancy Figueroa for their feedback on earlier versions of the manuscript.

\section{Conflicts of Interest:}

Dr. Mike Fralick and Ushma Purohit report no conflicts of interest. 


\section{References:}

1. World Health Organization. Coronavirus disease (COVID-2019) situation reports.

Available at: https://www-who-

int.myaccess.library.utoronto.ca/emergencies/diseases/novel-coronavirus-2019/situationreports. Accessed May 24, 2020.

2. Centers for Disease Control and Prevention. Infection Control: Severe acute respiratory syndrome coronavirus 2 (SARS-CoV-2). Available at:

https://www.cdc.gov/coronavirus/2019-ncov/infection-control/controlrecommendations.html\#Patient_Placement. Accessed March 25, 2020.

3. Yen MY, Lin YE, Lee CH, et al. Taiwan's traffic control bundle and the elimination of nosocomial severe acute respiratory syndrome among healthcare workers. J. Hosp. Infect. $2011 ; 77(4): 332-7$

4. Yen MY, Lin YE, Su IJ, et al. Using an integrated infection control strategy during outbreak control to minimize nosocomial infection of severe acute respiratory syndrome among healthcare workers. J. Hosp. Infect. 2006;62(2):195-9.

5. World Health Organization. Rational use of personal protective equipment for coronavirus disease 2019 (COVID-19). Available at: https://apps.who.int/iris/bitstream/handle/10665/331215/WHO-2019-nCov-IPCPPE_use2020.1-eng.pdf. Accessed March 24, 2020.

6. Guangming Y, Hualiang L, Liangjun C, et al. Environmental contamination of the SARSCoV-2 in healthcare premises: An urgent call for protection for healthcare workers. medRxiv preprint doi: https://doi.org/10.1101/2020.03.11.20034546. 